International Journal of Instruction e-ISSN: 1308-1470 • www.e-iji.net

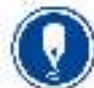

$$
\begin{array}{r}
\text { July } 2021 \bullet \text { Vol.14, No.3 } \\
\text { p-ISSN: } 1694-609 \mathrm{X} \\
\text { pp. 597-612 }
\end{array}
$$

Article submission code

20200725045324

Received: $25 / 07 / 2020$

Revision: 06/01/202
Accepted: 31/01/2021

OnlineFirst: 05/06/2021

\title{
Cross-Cultural Competence in Multicultural Education in Indonesian and New Zealand High Schools
}

\section{Zamroni}

Universitas Negeri Yogyakarta, Indonesia, zamronihardjowirono@yahoo.com

\section{Siti Irene Astuti Dwiningrum}

Universitas Negeri Yogyakarta, Indonesia, siti_ireneastuti@uny.ac.id

\section{John Hope}

The University of Auckland, Auckland New Zealand, j.hope@auckland.ac.nz

Badrun Kartowagiran

Universitas Negeri Yogyakarta, Indonesia, kartowagiran@uny.ac.id

\section{Titik Sudartinah}

Corresponding author, Universitas Negeri Yogyakarta, Indonesia, titiksudartinah@uny.ac.id

\section{Alexis Siteine}

The University of Auckland, Auckland New Zealand, a.siteine@auckland.ac.nz.

\section{Zhu Yao}

The University of Auckland, Auckland New Zealand, zyao410@aucklanduni.ac.nz

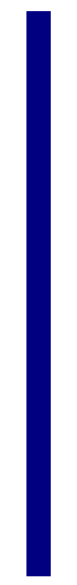

Equality in education is one of major concerns in culturally diverse societies like Indonesia and New Zealand. To achieve it, implementing multicultural education in senior high schools is an option. This research aims to reveal the students' crosscultural competence and to investigate the schools' strategies in implementing multicultural education in senior high schools in Yogyakarta, Indonesia and Auckland, New Zealand. The study used a concurrent embedded mixed-method design. The participants were 110 students and 24 teachers from 4 senior high schools in Yogyakarta, and 110 students and 10 teachers from 2 senior high schools in Auckland. Data were collected through questionnaires distributed to students, interviews with teachers, and class observations. The data collected were those related to the practices of multicultural education in these schools. The results show that the cross-cultural competence of Indonesian and New Zealand students is quite similar even though the practices of multicultural education are different in these countries. These differences occur due to the higher social and cultural diversity experienced by Indonesian students.

Keywords: cross-cultural competence, multicultural education, cultural diversity, Indonesia, New Zealand

Citation: Zamroni., Dwiningrum, S. I. A., Hope, J., Kartowagiran, B., Sudartinah, T., Siteine, A., \& Yao, Z. (2021). Cross-Cultural competence in multicultural education in Indonesian and New Zealand high schools. International Journal of Instruction, 14(3), 597-612. https://doi.org/10.29333/iji.2021.14335a 


\section{INTRODUCTION}

Multicultural education became a global commitment recommended in October 1994 by UNESCO in Geneva. This recommendation contained four ideas. First, education should develop the ability to acknowledge values of individuals, sexes, societies, and cultures and the ability to communicate, share, and cooperate with each other. Second, education should establish identity and encourage convergence of ideas and solutions to strengthen peace, brotherhood, and solidarity among individuals in the society. Third, education should increase the ability to overcome conflicts peacefully. Fourth, education should promote peacefulness in the mind of students so that they can build a higher quality of tolerance, patience, and will to share and maintain peace. Multiculturalism is based on the concept of nation states emphasizing regional, linguistic, and cultural union, thereby including cultural diversity within the political community. Thus, in building a multicultural society, it is important to consider the nature of citizenship (Åberg \& Mäkitalo, 2017; Cetin, 2013; Seeberg \& Minick, 2012).

However, only some parts of society understand the paradigm of multicultural education (Zamroni, 2011). There is also an assumption by some that multicultural awareness is not often introduced as a central component of teaching and learning, or even considered important in some facets of education. In fact, the paradigm is important since multicultural education can be seen as the center of education equality for all. Multicultural education is not simply a change in terms of curriculum or method of instruction (Mirza, Grossen, Diesbach-Dolder, \& Nicollin, 2014). It should be integrated in education. Otherwise, inequality is likely to increase. Multicultural education aims to bridge the gap between the curriculum and teacher's character, pedagogy, class situation, and school culture to promote equality in education ((Haas, 2019; Zamroni, 2011). Multicultural education is a process of social transformation. In this context, a progressive approach is needed to transform education. The concept of multicultural education should be reviewed and developed for the appropriate cultural context prior to its implementation in the teaching and learning process.

There is a strong need to develop multicultural education as a model to face growing global challenges. In the $21^{\text {st }}$ century, youth are increasingly challenged to have the ability to work across cultures and political boundaries. Thus, they need to increase their understanding of other cultures. They need to have a modern vision in an era of globalization. In the Indonesian context, youth need to take in the values of Unity in Diversity and implement them in society. Positive appreciation of ethnic identities such as culture, language, physical appearance, religion, and skin color is strikingly important (Cooper, 2014; Zamroni, 2011). Indonesia aims to become a nation with both national and global competence. That is why schools play an important role to prepare youth to possess a full understanding of national and global culture. As the world becomes more globalized, Indonesia has to be ready and more open to interact globally.

In reference to this need, the researchers collaborated with the University of Auckland in New Zealand because New Zealand is considered a country that has more successfully implemented multicultural education than Indonesia, built on New Zealand's amalgam of indigenous Maori, Pacific Island, Asian and European cultures. Indonesia needs to 
learn about it from New Zealand because Indonesia is also a multicultural country with more than 600 indigenous languages and cultures. There are structural and cultural constraints to establishing multicultural education policy at all Indonesian education levels. In addition, social problems due to the lack of understanding of a multicultural education perspective frequently occur. Therefore, a study of the practices of multicultural education in both countries is needed in order to provide an empirical resource for the development of Indonesian multicultural education based on the similarities and differences possessed by each country.

Multicultural education is a phenomenon that has become more prominent in the world of education as schools become increasingly diverse, suggesting a need for teacher preparation programs to provide teachers with the knowledge, skills, and dispositions to help all students learn (Aydin \& Ozfidan, 2014; Civitillo et al., 2016). In other words, multicultural education needs to be integrated in every single component of education.

Nieto (1992) explains that multicultural education aims to provide an anti-racial education, which takes into account basic skills and knowledge for all. It is important for all students and can help to break down barriers present in all levels of education systems. It contributes to the development of attitudes, knowledge, and skills that enable students to increase social capability, which is important for academic success (Byram, Nichols, \& Stevens, 2001). It emphasizes critical social knowledge and helps students develop their skills in making social decisions and attitudes. Banks (2016b) states that multicultural education is a way of thinking to face reality, not simply some knowledge of ethnicity, race, and culture. Banks (2016b) further describes five dimensions of multicultural education: content integration, the knowledge construction process, prejudice reduction, an equity pedagogy, and an empowering school culture and social structure, meaning there is a complex and multi-dimensional structure within multicultural education. Fulfilling all these five dimensions, students will have the capability to construct their ideals on the basis of what they learn. They will also develop an understanding of how they must react to social problems.

As its main goal is to improve the academic environment and atmosphere by increasing respect and attention addressed to various cultural groups to facilitate equality in education (J.A. Banks, 2016b), multicultural education becomes the most important goal of lifelong learning (Gollnick \& Chinn, 2017). The main issues related to multicultural education are social justice, democracy, and human rights (Tilaar, 2003). These aspects, even though closely related to economy, politics, and law, are also related to education. Education is important for preparing those who are oriented toward social justice, have democratic political vision, and respect others' rights. In short, multicultural education deals with political, social, cultural, moral, educational, and religious issues (Tilaar, 2003). It would be difficult to achieve a complete understanding of multicultural education without investigating these issues.

Multicultural education views schools as a social system composed of related elements and variables. Thus, to create a school that promotes this equal opportunity, all school elements need to be restructured substantially. If only one variable is changed, such as the curriculum, multicultural education cannot be implemented well (J.A. Banks, 
2016a). In addition, Suyata (2001) and Dervin, Paatela-Nieminen, \& Riitaoja (2012) note that to implement multicultural education in the education system, schools cannot be based on a single elite culture. They need to replace this culture with one that accommodates pluralism. Using this strategy, schools are more likely to get wider social support and participation.

Further, Suyata (2001) explains that in its efforts to minimize conflicts, multicultural education helps students: (1) understand the personal and cultural background of an individual or group in the society, (2) respect and appreciate the variety of culture and ethnicity, (3) undermine ethnocentric and prejudicial way of thinking, (4) understand social, economic, psychological, and historical factors that cause ethnic polarization, (5) increase the capability of analyzing problems critically through a democratic process to envision a better, fairer, and free society, and (6) develop a meaningful identity for everyone. Schools have a strategic role in implementing multicultural education since they are responsible socially for helping students to understand the continuing socialcultural transformations experienced by society. In relation to this, multicultural education can serve as a reformative act designed to produce transformations at schools so that students, regardless of their gender or ethnicity, will have the same opportunity to complete a globally appropriate education.

Historically in New Zealand, the need for understanding and respect for the different cultures of New Zealand is espoused as important. In fact, promoting the recognition and valuing of the experiences, cultural traditions, histories and languages of all New Zealanders has been explicit within national curriculum policy since 1993. Multicultural education (specifically liberal multiculturalism) focuses on cultural inclusiveness in the curriculum as well as the pedagogies used in teaching and learning that curriculum. However, teachers and educators do not necessarily bring blank intellectual and ideological slates to the area of multicultural education and diversity in education. They bring their own beliefs and assumptions about what constitutes quality teaching in settings where a range of different learners are located. They also bring their own knowledge, beliefs and assumptions about the diverse learners themselves, and the wider social and cultural groups that they represent and come from. Wlodkowski \& Ginsberg (1995), speaking as teachers at the tertiary level, offer the insight that these beliefs are culturally transmitted through history, religion, mythology, political orientation, and familial and media communication.

Understanding of multicultural education and diversity in education involves ideas, beliefs and understandings that social or societal change, even social transformation, is possible via schooling. Prejudice and racism in a heterogeneous society, for example, can be reduced by using sectors within the national compulsory education system to help young people learn tolerance, mutual understanding for difference and diversity, in all its forms. This can be achieved by not only learning about difference, but also learning how to interact with others who are different via language, including being able to enact other cultural moves and perform with competence in other socio-cultural contexts and settings (Nguyen, 2012). The ability to acknowledge and respect diversity is often termed as cross-cultural competence (Lynch, 2011; Magala, 2005). It evolves naturally 
as it is a lifelong process that needs to incorporate values and attitudes across diverse members of the society. Developing this competence, they can see clearly how cultures are structured and how they should deal with differences (Magala, 2005).

In the New Zealand context, the national policy on multicultural education cannot fully guarantee that the principles of multicultural education are well-implemented and understood by all in society, especially students. A study comparing the practices of multicultural education focusing on the social structure, social-cultural-economic backgrounds, and the relationship among teachers-students-parents is, therefore, as important to conduct In New Zealand as it is in Indonesia. Such study can also be an effective way to increase teachers' understanding of the important role of cross-cultural competence in their own country and globally.

This research is part of a larger project that aims to reveal the characteristics of multicultural education in high schools by comparing the practices of multicultural education in Yogyakarta, Indonesia and Auckland, New Zealand and to investigate how students experience multicultural education to develop their cross-cultural competence at school.

The study aims to answer the following research questions.

1. Regarding the practices of multicultural education, are there any differences in terms of the cross-cultural competence of students in Indonesia compared to that in New Zealand?

2. How do the Indonesian and New Zealand schools implement multicultural education?

This research was designed to have both theoretical and practical significance. Theoretically, it outlines the present state of basic practices of multicultural education implemented in both countries. Practically, it studies the cross-cultural competence outcomes supporting the success of multicultural education in high schools as well as the similarities and differences of the practices in Indonesian and New Zealand contexts.

\section{METHOD}

\section{Research Design}

This study used a concurrent embedded mixed method design. The collection of quantitative and qualitative data was done concurrently in one research phase (Creswell, 2014). The quantitative data were for revealing the cross-cultural competence of students in Indonesia and New Zealand, while the qualitative data were for identifying how schools employ some strategies to implement the principles of multicultural education.

\section{Participants}

The population of the research was students of senior high schools in Yogyakarta, Indonesia and Auckland, New Zealand. The schools were chosen due to their various social-cultural-economic backgrounds that reflect diverse ethnicities. The school sampling was done by choosing those whose students were from diverse ethnicities. In 
each school, one or two research assistants collected the data by distributing a questionnaire to students and collecting their answers. Random sampling technique was used and 110 students from 4 senior high schools responded in Yogyakarta and 110 students from 2 senior high schools responded in Auckland. Teacher opinion was ascertained after the data collection was done, with 24 teachers from 4 senior high schools in Yogyakarta and 10 teachers from two Auckland schools providing a teacher perspective. This discussion was to clarify the factual understanding and implementation of multicultural education in the schools.

\section{Instruments}

The quantitative data were collected through a questionnaire and the qualitative data were collected through interviews and observations. They were designed following a literature search for information about the general practices of multicultural education in Indonesia and New Zealand. Then, the validation of the questionnaires was conducted through construct validity using Confirmatory Factor Analysis (CFA), as presented in the following figure.

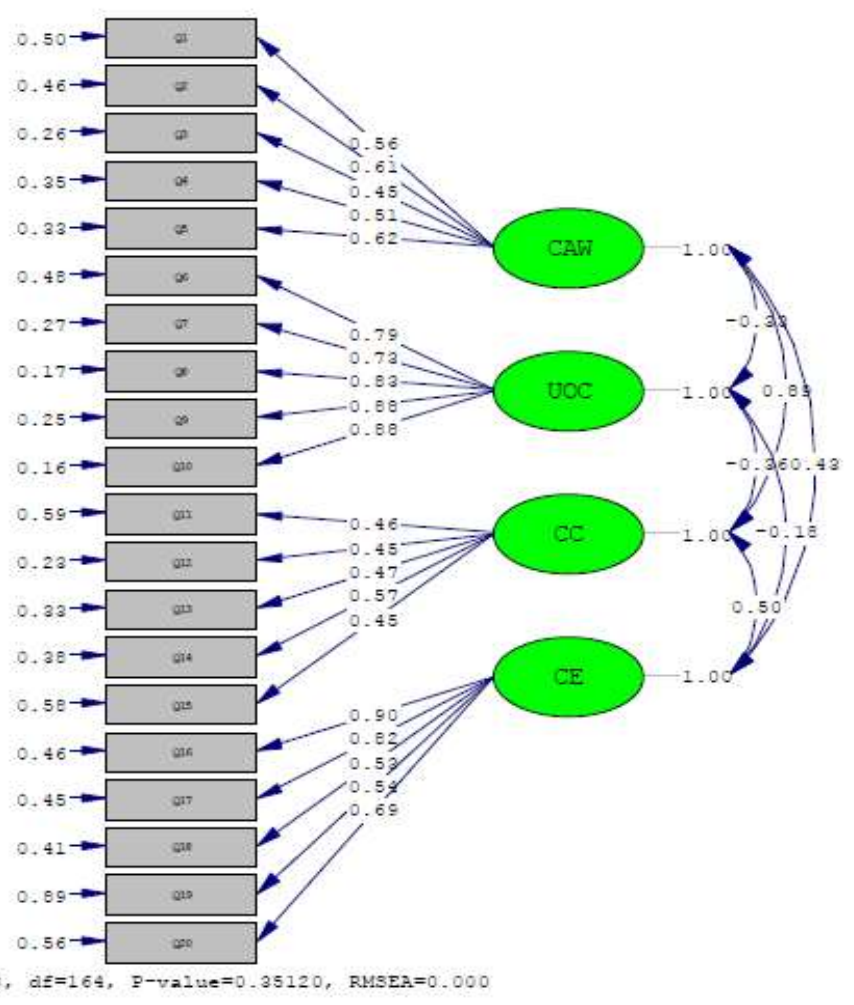

Figure 1

CFA result 
Figure 1 shows that the questionnaire used for collecting the data on the students' crosscultural competence in multicultural education in Indonesia and New Zealand is valid since the Chi-Square < $2 \mathrm{db}$; P-value > 0.05; RMSEA < 0.08 (Pedhazur, 1997). A closer look into the results reveals 4 factors related to the cross-cultural competence in multicultural education, i.e. cultural awareness, understanding of own and others' cultures, cultural competence, and cultural encounter. Each factor consists of 5 items and each item has a loading factor $(\alpha)>0.3$, meaning that all of the items are valid (Hair $\mathrm{Jr}$, Black, Babin, \& Anderson, 2014). The questionnaire is also reliable, with the reliability score 0.706 (Feldt \& Brennan, 1989). Meanwhile, the credibility of the qualitative data in the research was gained through triangulation, i.e. by cross-checking to various sources. Member checking, in addition, was also done by re-checking the information from the respondents.

\section{Data Analysis}

After the data were collected, data reduction was conducted to remove some data that did not match the criteria. These data were then categorized based on the themes to be revealed through this research. A mixed method was used in the data analysis; the quantitative analysis was using inferential statistic techniques and qualitative analysis was employed on the qualitative data. To measure the differences between the crosscultural competence of students in Indonesia and New Zealand, all four factors of multicultural education were compared and a MANOVA test was used.

\section{FINDINGS}

In order to reveal the students' cross-cultural competence, a questionnaire was distributed to all participants from 4 senior high schools in Yogyakarta and 2 senior high schools in Auckland. There are 4 factors tested, i.e. cultural awareness, understanding of own and others' cultures, cultural competence, and cultural encounter. The results are presented in the following table.

Table 1

Findings of the research

\begin{tabular}{|c|c|c|c|c|}
\hline & Group & Mean & Std. Deviation & $\mathrm{N}$ \\
\hline \multirow[t]{3}{*}{ Cultural Awareness } & New Zealand Group & 4.5382 & .56682 & 110 \\
\hline & Indonesian Group & 4.5345 & .43101 & 110 \\
\hline & Total & 4.5364 & .50236 & 220 \\
\hline \multirow{3}{*}{$\begin{array}{l}\text { Understanding of own and } \\
\text { Others' Cultures }\end{array}$} & New Zealand Group & 2.0018 & .81161 & 110 \\
\hline & Indonesian Group & 2.9800 & .70435 & 110 \\
\hline & Total & 2.4909 & .90282 & 220 \\
\hline \multirow[t]{3}{*}{ Cultural Competence } & New Zealand Group & 4.4073 & .59842 & 110 \\
\hline & Indonesian Group & 4.4891 & .43056 & 110 \\
\hline & Total & 4.4482 & .52172 & 220 \\
\hline \multirow[t]{3}{*}{ Cultural Encounter } & New Zealand Group & 3.6182 & 1.40237 & 110 \\
\hline & Indonesian Group & 3.6345 & .36735 & 110 \\
\hline & Total & 3.6264 & 1.02277 & 220 \\
\hline
\end{tabular}


As shown by the means in Table 1, there appear to be similar findings in terms of the cross-cultural competence of students in Indonesian and New Zealand high schools in three factors, i.e. cultural awareness, cultural competence, and cultural encounter.

The analysis using MANOVA also yields that there is no significant difference among the four factors between Indonesian and New Zealand students. This is presented in Table 2.

Table 2

MANOVA results

\begin{tabular}{|c|c|c|c|c|c|c|c|c|c|}
\hline \multicolumn{10}{|c|}{ Multivariate Tests $^{\mathrm{a}}$} \\
\hline Effect & & Value & $\mathrm{F}$ & $\begin{array}{l}\text { Hypothesis } \\
\text { df }\end{array}$ & Error df & Sig. & $\begin{array}{l}\text { Partial } \\
\text { Eta } \\
\text { Squared }\end{array}$ & $\begin{array}{l}\text { Noncent. } \\
\text { Parameter }\end{array}$ & $\begin{array}{l}\text { Observed } \\
\text { Power }^{\mathrm{c}}\end{array}$ \\
\hline \multirow[t]{4}{*}{ Intercept } & Pillai's Trace & .991 & $3329.915^{b}$ & 4.000 & 115.000 & .000 & .991 & 13319.669 & 1.000 \\
\hline & Wilks' Lambda & .009 & $3329.915^{\mathrm{b}}$ & 4.000 & 115.000 & .000 & .991 & 13319.669 & 1.000 \\
\hline & $\begin{array}{l}\text { Hotelling's } \\
\text { Trace }\end{array}$ & 115.823 & $3329.915^{\mathrm{b}}$ & 4.000 & 115.000 & .000 & .991 & 13319.669 & 1.000 \\
\hline & $\begin{array}{l}\text { Roy's Largest } \\
\text { Root }\end{array}$ & 115.823 & $3329.915^{\mathrm{b}}$ & 4.000 & 115.000 & .000 & .991 & 13319.669 & 1.000 \\
\hline \multirow[t]{4}{*}{ Countries } & Pillai's Trace & .050 & $1.500^{\mathrm{b}}$ & 4.000 & 115.000 & .207 & .050 & 6.001 & .453 \\
\hline & Wilks' Lambda & .950 & $1.500^{\mathrm{b}}$ & 4.000 & 115.000 & .207 & .050 & 6.001 & .453 \\
\hline & $\begin{array}{l}\text { Hotelling's } \\
\text { Trace }\end{array}$ & .052 & $1.500^{\mathrm{b}}$ & 4.000 & 115.000 & .207 & .050 & 6.001 & .453 \\
\hline & $\begin{array}{l}\text { Roy's Largest } \\
\text { Root }\end{array}$ & .052 & $1.500^{\mathrm{b}}$ & 4.000 & 115.000 & .207 & .050 & 6.001 & .453 \\
\hline
\end{tabular}

a. Design: Intercept+COUNTRIES

b. Exact statistic

c. Computed using alpha $=0.5$

In Table 2, Wilks' Lambda of Countries with $\mathrm{F}=1.500$ and $\mathrm{p}=0.207$ shows that there is no difference in terms of the cultural awareness, cultural competence, and cultural encounter between Indonesian and New Zealand students.

The only factor that differs Indonesian and New Zealand high schools is their understanding of own and others' cultures. This is presented in the following figure. 


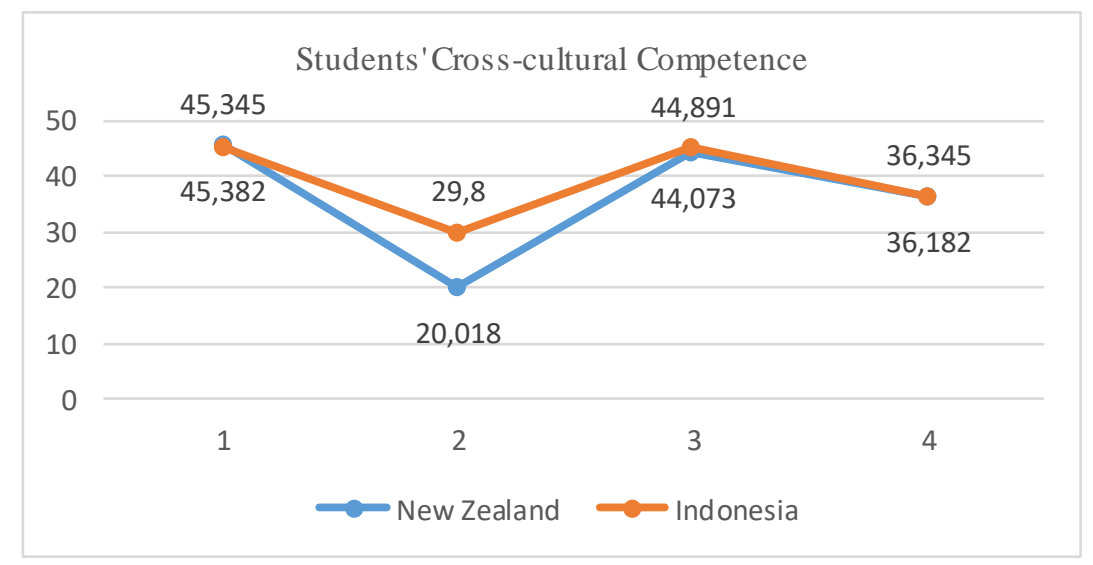

Figure 2

Students' cross-cultural competence

Notes: 1. Cultural awareness, 2. Understanding of own and others' cultures, 3. Cultural competence, 4. Cultural encounter

Based on the overall findings, there is only one factor that is different in the countries, i.e. understanding of own and others' cultures. This means that the difference in terms of the cross-cultural competence between the two groups is relatively small since the other three factors show the same result.

Meanwhile, to improve the cross-cultural competence of the students, some strategies are implemented by participating schools. These create more opportunities for students to experience multicultural education for building a higher understanding and respect for cultural differences. The strategies reflect some of the approaches of multicultural education stated by Banks (2016a), i.e. the contributions approach, the additive approach, the transformation approach, and the social action approach.

\section{DISCUSSION}

As presented in the findings, the only factor differing between the cross-cultural competence of senior high school students in Indonesia and New Zealand is understanding of own and others' cultures. This finding deserves investigation, especially in terms of the causal factors, either internal or external. The internal factors are related to the understanding of the concepts of multicultural education, students' personal experiences in their social life, and the students' motivation to appreciate differences and diversity. The external factors are related to the national policy, school policy, school culture, and the social culture in integrating the concepts of multicultural education at schools.

This difference between Indonesia and New Zealand may occur due to the higher diversity in Indonesia, which means that there is more opportunity for Indonesian students to experience more various social and cultural interactions. For instance, in 
terms of religion, more religions are present in Indonesia. In addition, in terms of ethnicities, Indonesian students live with a higher variety of ethnicities. Ethnicity is defined as the social organization of cultural difference, that is, the production and reproduction of difference in relation to other groups that creates a sense of similarity within the focal group (Jenkins, 2008). Hence, the process of identification within a group involves dialectic interplay between similarity and difference. Meanwhile, in New Zealand, diversity occurs in a larger scale since the students come from various countries. This is one differentiating feature in the implementation of multicultural education in both countries.

This implies that the Indonesian students have more opportunities to have new friends coming from different regions, living in different areas, and interacting with those with different ethnicities and religions. This is in line with the concept of symbolic interactionism introduced by George Herbert Mead, that a person develops his social competence, including the cultural competence, through social processes (Ahmadi, 2008). Furthermore, Charon (2010) mentions that the processes can be described in a certain pattern, of which the elements are the language used and the social objects and points of view. The processes come in the form of social interactions using dynamic symbols and the ability of a person to understand these symbols is influenced by socialization of the context in which the symbols occur, the actual content and processes people use to socialize others, and the results arising from those contexts and processes (Ahmadi, 2008; Magala, 2005).

Socialization becomes an important element influencing the formation of cross-cultural competence because it is a central process in social life (Convertino, Levinson, \& González, 2016; Magala, 2005; Persell, 1990). The society, thus, is seen as the primary factor responsible for how individuals learn to think and behave. In relation to this, students living in a multiethnic area usually need to have a higher motivation to adapt to the social life rather than those living in a monoethnic society. Therefore, it is important for students living in this setting to learn to develop their personality, regarding the personal and social competence, such as the ability to communicate effectively in a multiethnic society. Cultural awareness, thus, is an important element to build crosscultural competence (Madden, 2015). In addition, multicultural perspectives can be introduced to students through practices that are legally based on the national policy regarding multicultural education.

In the Indonesian context, although multicultural education is not officially acknowledged as a part of its national policies, its national slogan Bhinneka Tunggal $I k a$, which means Unity in Diversity, serves as the basis of the multicultural practices in Indonesian schools. The practices of multicultural education are infused in the curriculum and integrated in the subjects. In addition, schools designed many programs that represent the goal of multicultural education. This is in line with what is presented in the National Act on Education System Article 4 Section 1, which mentions that education is held in a democratic and non-discriminative way. Some other activities reflecting the practice of multicultural education are student exchange programs between regions or countries, singing national anthem in any official occasion, 
integrating the concept of Unity in Diversity in the curriculum, and provide no discrimination in school services. If well-established, incorporating multicultural values through such programs can prevent cultural conflicts between students (Syahbudin \& Hanafi, 2017).

On the other hand, historically in New Zealand, the need for understanding and respecting the different cultures of New Zealand is espoused as important. In fact, promoting the recognition and valuing of the experiences, cultural traditions, histories and languages of all New Zealanders has been explicit to national curriculum policy since 1993. In the last 20 years New Zealand schooling has increasingly focused on implementing the historic 1840 Treaty of Waitangi between the indigenous Maori people of New Zealand and the British Queen Victoria. All schools are now required to teach Maori language and culture and Maori cultural observances are implicit in all national activities. Another influence is the migration of large numbers of Polynesian families to New Zealand and the most recent migration of Asian families. Most of the immigrants settle in Auckland, making Auckland the most culturally diverse city in the world. Multicultural education (specifically liberal multiculturalism) focused on cultural inclusiveness in the curriculum as well as the pedagogies used in teaching and learning that curriculum has thus become increasingly important in New Zealand, and particularly in Auckland where the New Zealand data for this study was collected.

Even though the results of the present research show that there is a difference in terms of the understanding of own and others' cultures, the major findings suggest that the crosscultural competence of Indonesian and New Zealand students is quite similar, shown by the similarities in the other three factors. These similarities are resulted from the multicultural composition of the population in both countries and various efforts done by both countries in pursuing the goal of multicultural education.

Despite of the fact that there is no official policy regarding the practice of multicultural education in both countries, schools in general already implement the principles of multicultural education by providing facilities to accommodate students' talents and interests regardless of their ethnicity, origin, and social status. Besides, schools also partner with other schools in both the national and international levels. In the focus group discussion held in Yogyakarta, the participants acknowledge several other programs related to the principles of multicultural education, such as multitalent program that aims to develop the potential of students, a program promoting tolerance and respect towards other cultures, freedom to do religious services, and staff exchanges.

These strategies are infused in the curriculum and integrated in all the school subjects. They reflect most approaches of multicultural education that Banks (2016a) states, i.e. the contributions approach, the additive approach, the transformation approach, and the social action approach. Some examples of each strategy in integrating multicultural education principles are presented in the following table. 
Table 3

Strategies to implement multicultural education

Strategy
The contributions approach
This is the most common approach, which
is also the first stage of ethnic revival. One
of the examples of its use is putting the
images of national heroes coming from
various ethnicity and culture in related
school subjects.
school subjects.
Description

1. Putting symbols reflecting diverse cultures

2. Introducing national heroes to build good characters

3. Design school environment with various culture-related materials

4. Naming classes with countries names and providing their artefacts

5. Writing announcements in two or more languages
The additive approach

In this stage, there is an effort to enrich learning materials, concepts, themes, and perspectives in the curriculum without any changes in the basic structures, objectives, and characteristics of the curriculum. This approach is supplemented with books, modules, or discussions that do not lead to any substantial changes in the curriculum.

The transformation approach

This approach is different from the previous ones since it changes the basic assumptions of a curriculum and promote students' competence in addressing concepts, issues, themes, and problems using some ethnic perspectives that center on the main item discussed in subjects.

The social action approach

This approach includes all elements in the transformation approach, with an additional component that inquires students to make actions related to learnt materials in school subjects. Its main goal is to teach students to deliver social criticisms and make decisions. In this case, schools help students become reflective social critics and trained participants to respond to social changes.

1. Designing curriculum with multicultural education content

2. Providing elective extracurricular programs

3. Reading books of culture

4. Using various cooperative learning models in classes

5. Creating interdisciplinary programs

6. Providing more references highlighting culture

1. Habit-forming appreciation of diversity at schools

2. Discussing social problems in a multicultural society

3. Exploring and showing cultural diversity to students

4. Understanding and respecting others through various programs

1. Accepting students from various socialeconomic-cultural backgrounds

2. Providing student exchange programs to other countries such as Japan, South Korea, Thailand, and Malaysia

3. Sending a brand ambassador in various cultural events

4. Randomly dividing classes regardless of the status of the students

5. Putting students in classes regardless of their religions

6. Emphasizing on cooperation in providing school services

7. Holding many kinds of activities with students

Table 3 shows that there are many strategies used in the practices of multicultural education in both countries. The use of these strategies creates opportunities for various 
meaningful experiences because the perceptions of multicultural education are built comprehensively in order to develop the students' cross-cultural competence. With more chances to experience diversity, students can develop their ability in learning and adapting to diverse cultures.

Even though the practices of multicultural education in Indonesia and New Zealand differ in terms of their details, some basic similarities are seen. The society in both countries respect and appreciate diversity using their own strategies due to differences in the structural and cultural situation. For instance, the schools in both countries recognize that they need to consistently transfer the knowledge of social and cultural diversity to their students to build the students' cultural awareness. In addition, this transfer can also occur through various programs that schools have systematically designed. The opportunities to interact with other students from different social and cultural backgrounds increase the students' chances to improve their cross-cultural competence and therefore, play a role in their achievement.

\section{CONCLUSION}

This study provides insights to people in the education field, that multicultural education needs to be taught, integrated and implemented in the most appropriate way in order that the goals be fulfilled. A prior consideration of the social and cultural settings is needed before a program can be designed. Compared to New Zealand, Indonesia has traditionally been built on a higher variety of social and cultural elements such as ethnicities, religions, and languages, so multicultural education has become a more complicated issue there. Although New Zealand has been a monocultural society in the past, recent migration and government policies to implement Maori cultural values in all aspects of society has created a transformation of New Zealand into a multicultural society, particularly in Auckland.

However, the results of this study suggest that the cross-cultural competence of high school students in both countries are similar in most factors. The only difference is in terms of the understanding of own and others' cultures, which may be accounted for the traditionally higher exposures of social and cultural diversity that Indonesian students experience in contrast to the more recent New Zealand experience. To sum up, although the detailed practices of multicultural education in both countries are different, they orient towards the same goal, that is, providing equal and non-discriminative education for all students.

\section{ACKNOWLEDGMENTS}

The authors would like to thank all students and teachers for their participation in the study in Indonesia and New Zealand. In addition, gratitude is also expressed to Direktorat Jenderal Penguatan Riset dan Pengembangan, Kementerian Riset, Teknologi, dan Pendidikan Tinggi for funding this study under Grant DIPA042.06.1.401516/2017. 


\section{REFERENCES}

Åberg, L., \& Mäkitalo, Å. (2017). Integration work as a situated communicative practice: Assuming, establishing and modifying cultural di ff erences. Learning, Culture and Social Interaction, 15, 56-68. https://doi.org/10.1016/j.lcsi.2017.07.002

Ahmadi, D. (2008). Interaksi simbolik: Suatu pengantar. Mediator, 9(2), 301-316.

Aydin, H., \& Ozfidan, B. (2014). Perceptions on mother tongue (Kurdish) based multicultural and bilingual education in Turkey. Multicultural Education Review, 6(1), 21-48.

Banks, J.A. (2016a). Approaches to multicultural curriculum reform. In J.A. Banks \& C. A. M. Banks (Eds.), Multicultural Education: Issues and Perspectives (9th ed., pp. 151170). New Jersey: John Wiley \& Sons, Inc.

Banks, J.A. (2016b). Multicultural education: Characteristics and goals. In J.A. Banks \& C. A. M. Banks (Eds.), Multicultural Education: Issues and Perspectives (9th ed., pp. 2-23). New Jersey: John Wiley \& Sons, Inc.

Byram, M., Nichols, D., \& Stevens, D. (2001). Introduction. In M. Byram, D. Nichols, \& D. Stevens (Eds.), Developing Intercultural Competence in Practice. Clevedon: Multilingual Matters Ltd.

Cetin, I. (2013). The possibility of multiculturalism in a nation state: A debate on Europe and Millet system. Studia Sociologica V, 2, 73-85.

Charon, J. M. (2010). Symbolic interactionism: An introduction, an interpretation, an integration (10th ed.). Boston: Prentice Hall.

Civitillo, S., Schachner, M., Juang, L., Vijver, F. J. R. Van De, Handrick, A., \& Noack, P. (2016). Towards a better understanding of cultural diversity approaches at school: A multi-informant and mixed-methods study. Learning, Culture and Social Interaction, 12, 1-14. https://doi.org/10.1016/j.lcsi.2016.09.002

Convertino, C., Levinson, B. A., \& González, N. (2016). Culture, teaching, and learning. In James A. Banks \& C. A. M. Banks (Eds.), Multicultural Education: Issues and Perspectives (9th ed., pp. 24-40). New Jersey: John Wiley \& Sons, Inc.

Cooper, C. R. (2014). Cultural brokers: How immigrant youth in multicultural societies navigate and negotiate their pathways to college identities. Learning, Culture and Social Interaction, 3(2), 170-176. https://doi.org/10.1016/j.lcsi.2013.12.005

Creswell, J. W. (2014). Research Design: Qualitative, Quantitative, and Mixed Methods Approaches (4th ed.). Los Angeles: SAGE Publications, Inc.

Dervin, F., Paatela-Nieminen, M., \& Riitaoja, A.-L. (2012). Multicultural Education in Finland : Renewed Intercultural Competencies to the Rescue ?, 14(3), 1-13. 
Feldt, L. S., \& Brennan, R. L. (1989). Realiability. In The American Council on Education/Macmillan series on higher educatio. Educational measurement (pp. 105146). New York: Macmillan Publishing Co, Inc; American Council of Education.

Gollnick, D. M., \& Chinn, P. C. (2017). Multicultural Education in a Pluralistic Society (10th ed.). Boston: Pearson Education, Inc.

Haas, B. W. (2019). Enhancing the Intercultural Competence of College Students : A Consideration of Applied Teaching Techniques. International Journal of Multicultural Education, 21(2), 81-96.

Hair Jr, J. F., Black, W. C., Babin, B. J., \& Anderson, R. E. (2014). Multivariate Data Analysis (7th Editio). Essex: Pearson Education Ltd.

Jenkins, R. (2008). Rethinking Ethnicity: Arguments and Ecplorations (2nd ed.). London: SAGE Publications, Ltd.

Lynch, E. W. (2011). Developing cross-cultural competence. In E. W. Lynch \& M. J. Hanson (Eds.), Developing Cross-Cultural Competence: A Guide for Working with Children and Their Families (pp. 71-116). Maryland: Paul H. Brookes Publishing Co.

Madden, E. S. (2015). Cultural self-awareness. In The SAGE Encyclopedia of Intercultural Competence (pp. 177-178). SAGE Publications, Inc.

Magala, S. (2005). Cross-Cultural Competence. London: Routledge.

Mirza, N. M., Grossen, M., Diesbach-Dolder, S. de, \& Nicollin, L. (2014). Transforming personal experience and emotions through secondarisation in education for cultural diversity: An interplay between unicity and genericity. Learning, Culture and Social Interaction, 3(4), 263-273. https://doi.org/10.1016/j.lcsi.2014.02.004

Nguyen, H. (2012). Social interaction and competence development: Learning the structural organization of a communicative practice. Learning, Culture and Social Interaction, 1(2), 127-142. https://doi.org/10.1016/j.lcsi.2012.05.006

Nieto, S. (1992). Affirming Diversity: The Sociopolitical Context of Multicultural Education. New York: Longman.

Pedhazur, E. J. (1997). Multiple Regression in Behavioral Research: Explanation and Prediction. Victoria: Thomson Learning.

Persell, C. H. (1990). Understanding Society: An Introduction to Sociology (3rd ed.). New York: Harper \& Row Publishers, Inc.

Seeberg, V., \& Minick, T. (2012). Enhancing Cross-cultural Competence in Multicultural Teacher Education: Transformation in Global Learning. International Journal of Multicultural Education, 14(3), 1-22.

Suyata, S. (2001). Menata kembali pendidikan bangsa dan masyarakat Indonesia baru: Sekolah, universitas, dan masyarakat madani. Dinamika Pendidikan, 8(1), 79-94. 
Syahbudin, Z., \& Hanafi, M. (2017). The model of learning design based on Islamic multicultural education to prevent conflicts of behavior. Jurnal Pendidikan Islam, 3(2), 155-168. https://doi.org/10.15575/jpi.v3i2.1279

Tilaar, H. A. R. (2003). Kekuasaan dan Pendidikan: Suatu Tinjauan dari Perspektif Studi Kultural. Magelang: Yayasan Indonesia Tera.

Wlodkowski, R. J., \& Ginsberg, M. B. (1995). A framework for culturally responsive teaching. Educational Leadership, 53(1), 17-21.

Zamroni, Z. (2011). Pendidikan Demokrasi pada Masyarakat Multikultural. Yogyakarta: Gavin Kalam Utama. 